\title{
Pengaruh Bauran Promosi Terhadap Keputusan Nasabah Dalam Menggunakan Tabungan ib Hasanah Pada PT. BNI Syariah Cabang Palu
}

\author{
Moh Fauzan ${ }^{1 *}$ Ubay Harun ${ }^{2}$, Sofyan Bachmid ${ }^{3}$ \\ ${ }^{1}$ Jurusan Perbankan, Fakultas Ekonomi dan Bisnis Islam, IAIN Palu \\ ${ }^{2}$ Jurusan Perbankan, Fakultas Ekonomi dan Bisnis Islam, IAIN Palu \\ ${ }^{3}$ Jurusan Perbankan, Fakultas Ekonomi dan Bisnis Islam, IAIN Palu
}

ABSTRAK

INFORMASI

ARTIKEL

Tujuan penelitian ini adalah untuk mengetahui pengaruh bauran promosi terhadap keputusan nasabah dalam menggunakan tabungan iB Hasanah pada PT. BNI Syariah Cabang Palu. pengaruhperiklanan, promosi penjualan, hubungan masyarakat, penjualan personal, dan pemasaran langsung terhadap keputusan nasabah dalam menggunakan tabungan iB Hasanah. Penelitian ini merupakan penelitian yang bersifat kuantitatif. Sampel yang digunakan dalam penelitiaan ini sebanyak 60 responden yang merupakan nasabah yang menggunakan tabungan iB Hasanah pada PT. BNI Syariah Cabang Palu. Metode yang digunakan untuk menguji hipotesis adalah regresi linear berganda.Hasil penelitian menunjukkan variabel bauran promosi secara serempak berpengaruh terhadap keputusan nasabah. Periklanan berpengaruh signifikan secara parsial terhadap keputusan nasabah, promosi penjualan berpengaruh signifikan secara parsial terhadap keputusan nasabah, hubungan masyarakat berpengaruh tidak signifikan secara parsial terhadap keputusan nasabah, penjualan personal berpengaruh signifikan secara parsial terhadap keputusan nasabah, pemasaran langsung berpengaruh tidak signifikan secara parsial terhadap keputusan nasabah.

Katakunci:

Bauran promosi, keputusan nasabah, tabungan ib Hasanah, BNI Syariah 


\section{PENDAHULUAN}

Peran perusahaan jasa dewasa ini mendominasi kehidupan masyarakat dalam kaitannya dengan aktivitas ekonomi, perusahaan yang bergerak dibidang jasa khususnya industri perbankan merupakan salah satu pemain ekonomi Indonesia yang menjadi salah satu tulang punggung harapan bangsa. Sehingga mau tidak mau perusahaan jasa yang bergerak pada industri perbankan harus memperhatikan kualitas produk atau jasa yang mereka jual. ${ }^{1}$

Lembaga perbankan merupakan financial intermediary (perantara keuangan) yang mempunyai peranan sangat vital dalam struktur perekonomiannegara. Bank menyerap dana masyarakat dan menyalurkan kembali kepada masyarakat. Sedemikian strategisnya peranan bank dalam pembangunan perekonomian negara,sehingga setiap negara berusaha menciptakan suatu sistem perbankan yang sehat, tangguh, dan dapat memelihara kepercayaan masyarakat. $^{2}$

Didirikannya bank syariah ini dilatarbelakangi oleh keinginan umat Islam

${ }^{1}$ Iman Agus Faisal, "Pengaruh Bauran Promosi Terhadap Keputusan Nasabah Pada Pt. Bni Cabang Palu", (Skripsi, Jurusan Manajemen Fakultas Ekonomi Universitas Tadulako, 2016), 4. (Diakses 10 Mei 2017).

${ }^{2}$ Darma, "Pengaruh Bauran Promosi Terhadap Keputusan Pembelian Produk Pembiayaan KPR Platinum iB Pada Bank X Syariah Cabang Harmoni Jakarta", Jurnal Ekonomi dan Bisnis, Vol 12, No. 1 (Juni 2013), 8 (Diakses 25 Mei 2017) untuk menghindari adanya riba dalam kegiatan muamalahnya, memperoleh kesejahteraan lahir dan batin melalui kegiatan muamalah yang sesuai dengan perintah agama, sebagai alternatife lain dalam menikmati jasa-jasa perbankan yang dirasakan lebih sesuai, yaitu bank yang berusaha sebisa mungkin untuk beroperasi berlandaskan kepada hukum-hukum Islam.

Bank Syariah di Indonesia telah mendapatkan legitimasi dalam Undangundang Perbankan Nomor 7 tahun 1992 yang kemudian diubah dengan Undangundang Perbankan Nomor 10 tahun 1998. Bank-bank baik bank konvensional maupun bank syariah selalu beroperasi dengan menyimpan dana dari nasabah kreditur dan meminjamkan dana tersebut kepada debitur. Implementasi dari alternatif ini adalah dikembangkannya kegiatan usaha bank berdasarkan prinsip syariah yang operasinya tidak didasarkan atas metode bunga, melainkan dengan metode bagi hasil. ${ }^{3}$

Dijelaskan dalam Q.S Ali $\operatorname{Imran}(3): 130$ yang berbunyi :

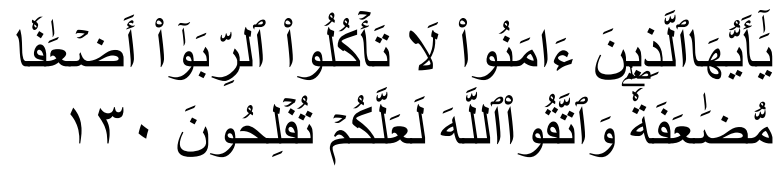

Terjamahanya:

"Hai orang-orang yang beriman, janganlah kamu memakan riba dengan

${ }^{3}$ Andri Soemitra, Bank dan Lembaga Keuangan Syari'ah, (Jakarta: Kencana Prenada Media Group), 22. 
berlipat ganda dan bertakwalah kamu kepada Allah supaya kamu mendapat keberuntungan". ${ }^{4}$

Keseluruhan perusahaan juga mempunyai beberapa tujuan yang ingin dicapai termasuk PT. BNI Syariah Cabang Palu. Tujuan utamanya adalah memperoleh laba atau keuntungan dan mensejahterahkan karyawan. Dengan adanya laba yang diterima, maka PT. BNI Syariah Cabang Palu dapat mempertahankan dan memperluas usahanya. Untuk mencapai tujuan yang diharapkan, maka diperlukan adanya beberapa kegiatan, antara lain kegiatan pemasaran dari suatu produk yang dihasilkan perusahaan. Kegiatan pemasaran tidak hanya membahas produk, harga produk, dan mendistribusikan produk, tetapi juga mempromosikan produk tersebut kepada masyarakat, agar produk itu dikenal dan pada akhirnya dibeli.

\section{PT. BNI Syariah Cabang Palu} merupakan satu-satunya kantor cabang di Provinsi Sulawesi Tengah, sehingga diperlukan strategi pemasaran yang sesuai untuk memenangkan persaingan dalam industri perbankan. Berbagai usaha harus dilakukan untuk menambah jumlah nasabah dan terus diupayakan secara berulang, dan bila hal ini dapat dilakukan dan

\footnotetext{
${ }^{4}$ Kementrian Agama Republik Indonesia, AlQur'an dan Terjemahnya (Surabaya: Mekar Surabaya, 2002), 288.
}

dipertahankan, maka bank dapat berkembang secara dinamis. Oleh karena itu, PT. BNI Syariah Cabang Palu melakukan kebijakan promosi dengan tepat dan memahami dengan benar pasar sasarannya. Karena apabila tidak dilakukan kebijakan promosi yang tepat kepada nasabah, maka akan berdampak pada berkurangnya nasabah di setiap bank yang beroperasi.

Kebijakan promosi yang tepat merupakan salah satu faktor penentu keberhasilan suatu program pemasaran. Hal ini karena pada dasarnya tujuan akhir dari penyampaian produk/jasa adalah nasabah, sedangkan kondisi nasabah saat ini sudah mulai sensitif dan mampu bertindak logis sehingga lebih selektif terhadap pembelian produk/jasa. PT. BNI Syariah Cabang Palu dalam kebijakan promosinya menggunakan variabel periklanan, promosi penjualan, hubungan masyarakat, penjualan personal dan pemasaran langsung, sehingga nasabah bisa lebih percaya, mengerti atau paham, dan memiliki keyakinan untuk melakukan pembelian produk/jasa.

Menurut Kotler dan Armstrong terdapat lima kegiatan dalam bauran promosi, ${ }^{5}$ yaitu :

1. Periklanan

2. Promosi penjualan

3. Hubungan masyarakat

${ }^{5}$ Philip Kotlerdan Gary Armstrong.Prinsip PrinsipPemasaranEdisi Keduabelas, jilid 2,(Jakarta: Penerbit Erlangga 2008), 117. 
4. Penjualan personal

5. Pemasaran langsung

Bauran promosi baik secara langsung maupun tidak langsung dapat mempengaruhi peningkatan jumlah nasabah untuk menabung pada PT. BNI Syariah Cabang Palu dengan menggunakan media periklanan (papan nama, radio, brosur, surat kabar, dan spanduk) memiliki tujuan tertentu, yakni secara tidak langsung perusahaan ingin mengenalkan produk jasa iB Hasanah kepada masyarakat luas, dan sekaligus sebagai sarana perluasan pasar.

Promosi penjualan juga merupakan strategi promosi yang dilakukan oleh PT. BNI Syariah Cabang Palu untuk memasarkan produk jasa iB Hasanah kepada masyarakat. Promosi yang digunakan, yaitu dengan pemberian souvenir kepada nasabah baru, menawarkan jaminan keamanan terhadap tabungan nasabah, dan juga mengadakan undian berhadiah setiap tahunnya.

Melalui hubungan masyarakat PT. BNI Syariah Cabang Palu telah melakasanakan kegiatan kemanusiaan sekaligus mengenalkan kelembagaannya kepada masyarakat, misalnya seorang pembicara pada acara seminar ilmiah, pidato keilmuan, ataupun diskusi terbuka serta mengadakan bakti sosial bagi masyarakat yang kurang mampu, penggalangan dana bagi korban bencana, dan turut serta dalam kegiatan kerja bakti untuk membersihkan lingkungan. Dengan membangun hubungan masyarakat yang dinamis dan harmonis, maka secara tidak langsung citra perusahaan di mata masyarakat akan baik.

Penjualan personal juga merupakan strategi promosi yang dilakukan PT. BNI Syariah Cabang Palu dalam mempromosikan produk jasa iB Hasanah kepada masyarakat, misalnya pihak bank berkunjung ke rumah calon nasabah, menggunakan jasa agen penjualan dan pihak bank bertemu langsung dengan calon nasabah di kantor cabang. Hal tersebut merupakan cara yang paling mudah untuk menciptakan kepercayaan calon nasabah, agar menggunakan produk jasa PT. BNI Syariah Cabang Palu, dikarenakan secara langsung pihak bank dapat mempengaruhi keputusan calon nasabah untuk menggunakan produk jasa iB Hasanah.

Pemasaran langsung yang juga merupakan strategi promosi yang dilakukan oleh PT. BNI Syariah Cabang Palu diharapkan dapat meningkatkan jumlah nasabah yang ingin menabung di bank BNI Syariah. Penggunaan media, seperti surat langsung dan telemarketing oleh bank memiliki tujuan tertentu, yakni pihak bank dapat lebih leluasa untuk menginformasikan produk jasa iB Hasanah kepada para calon nasabah. 


\section{TINJAUAN PUSTAKA}

\subsection{Bauran Promosi}

Salah satu upaya agar produk yang dihasilkan dapat diterima konsumen adalah dengan melaksanakan promosi secara tepat dan terpadu sesuai dengan situasi dan kondisi perusahaan. Kegiatan promosi dapat dilakukan dengan berbagai cara seperti : advertising, personal selling, sales promotion, dan publisitas.

Promosi adalah sejenis komunikasi yang memberikan pengeluaran yang meyakinkan kepada calon konsumen tentang barang dan jasa, yang mempunyai tujuan untuk memperoleh perhatian, mendidik, mengingatkan dan menyakinkan calon kosumen.Promosi merupakan salah satu faktor penentu keberhasilan suatu program pemasaran. Pada hakikatnya promosi adalah salah satu bentuk komunikasi pemasaran. Pentingnya promosi dapat digambarkan dalam perumpamaan bahwa pemasaran tanpa promosi dapat diibaratkan seorang pria berkaca mata hitam yang dari tempat gelap pada malam kelam mengedipkanmatanya pada seorang gadis cantik dikejauhan. Tak seorang pun yang tahu apa yang dilakukan pria tersebut selain dirinya. ${ }^{6}$

Promosi juga merupakan berbagai kegiatan yang dilakukan perusahaan dengan

\footnotetext{
${ }^{6}$ Tjiptono, F. Strategi Pemasaran, Edisi Ketiga, (Yogyakarta: CV. Andi Offset, 2008), 219.
}

tujuan utama untuk menginformasikan, membujuk, mempengaruhi dan mengingatkan konsumen agar membeli produk yang dihasilkan. Untuk melaksanakan kegiatan promosi produk perusahaan secara keseluruhan khususnya kegiatan penjualan, maka produsen harus memilih dan menetapkan secara seksama elemen-elemen dalam bauran promosi (promotion mix) yang terdiri dari 5 (lima) yaitu periklanan, promosi, hubungan masyarakat, penjualan pribadi, dan pemasaran langsung. ${ }^{7}$

Dalam Islam, dilarang keras melakukan penipuan, kebohongan dan mengingkari janji. Oleh karena itu dalam pelaksanan promosi pebisnis muslim harus menghindari tindakan kebohongan, janji palsu, iklan porno, serta publikasi produk yang menghalalkan segala cara. Dusta sangat ditentang oleh Islam sebagaimana disebutkan dalam Q.S An-Nahl(16) ayat 91 sebagai berikut:
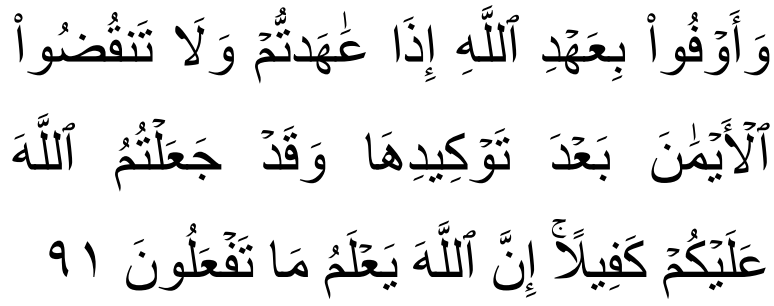

Terjemahanya:

"Dan tepatilah perjanjian dengan Allah apabila kamu berjanji dan janganlah kamu membatalkan

${ }^{7}$ Tjiptono, F. Strategi Pemasaran, 222. 
sumpah-sumpah(mu) itu, sesudah meneguhkannya, sedang kamu telah menjadikan Allah sebagai saksimu (terhadap sumpah-sumpahmu itu). Sesungguhnya Allah mengetahui apa yang kamu perbuat". 8

Ayat di atas menjelaskan bahwa setiap manusia diwajibkan menepati janji yang telah di tetapkan, demikian juga dengan pelaku bisnis baik janji yang ditetapkan secara langsung maupun janji-janji dalam bentuk promosi, semuanya harus ditepati dan sesuai dengan kenyataan. Penawaran ketika promosi atau iklan yang tidak sesuai dengan kenyataan berarti telah mengingkari janji yang ditetapkan dan hal ini telah mengandung unsur penipuan yang akan merugikan konsumen. ${ }^{9}$

Menurut Kotler dan Amstrong bauran promosi adalah paduan spesifik periklanan, promosi penjualan, hubungan masyarakat, penjualan personal dan sarana pemasaran langsung yang digunakan perusahaan untuk mengkomunikasikan nilai pelanggan secara persuasif dan membangun hubungan pelanggan.

Dalam menentukan bauran promosi, perusahan dapat memilih sebuah strategi

\footnotetext{
${ }^{8}$ Kementrian Agama Republik Indonesia, AlQur'an dan Terjemahnya (Surabaya: Mekar Surabaya, 2002), 223.

${ }^{9}$ Sofyan Bachmid. “ Konsep Kualitas Layanan Dan Implikasinya Terhadap Kepuasan Mahasiswa”. Jurnal Finlansia(2012). 11

http://www.academia.edu/4705098/KONSEP KUALITAS LAYANAN DAN_IMPLIKASINYA _TERHADAP_KEPUASAN_MAHASISWA_OLEH SOFYAN_BACHMID (diakses 15 Juni 2017)
}

yang tepat. Menurut Kotler \& Amstrong terdapat dua strategi bauran promosi yaitu strategi promosi dorong (push) dan strategi promosi tarik (pull). ${ }^{10}$

Dari definisi di atas dapat disimpulkan bahwa bauran promosi adalah kombinasi alat-alat promosidari perilaku manusia yang tidak dapat dipisahkan sebelum menetapkan keputusan untuk menggunakan dan membeli barang atau jasa yang bernilai ekonomis.

Menurut Kotler dan Armstrongterdapat lima kegiatan dalam bauran promosi yaitu periklanan, promosi penjualan, hubungan masyarakat, penjualan personal, dan pemasaran langsung ${ }^{11}$, yaitu:

a. Periklanan merupakan sasaran perusahaan untuk mempengaruhi konsumen dan sebagai alat persaingan dengan perusahaan lain dalam usaha mendapatkan perhatian dan kesan dari pasar sasaran. Alat-alat promosi iklan antara lain media cetak, siaran, brosur, poster, billboard dan lain-lain.segala bentuk penyajian dan promosi ide, barang, atau jasa secara non personal oleh suatu sponsor tertentu yang memerlukan pembayaran.

\footnotetext{
${ }^{10}$ Budianto, Apri. Manajemen Pemasaran, Edisi Revisi, (Yogyakarta: Penerbit Ombak, 2015), 330.

${ }^{11}$ Philip Kotler dan Gary Armstrong. Prinsip - PrinsipPemasaranEdisi Keduabelas, jilid 2, (Jakarta: Penerbit Erlangga, 2008), 11.
} 
b. Promosi penjualan dapat dilakukan dengan berbagai macam media, akan tetapi pada dasarnya kegiatan promosi penjualan dapat memberikan kontribusi bagi penjualan secara cepat.Terdiri dari kumpulan alat - alat insentif yang beragam, sebagian besar berjangka pendek, di rancang untuk mendorong pembelian suatu produk/jasa tertentu secara lebih cepat dan/atau lebih besaroleh konsumen atau pedagang ${ }^{12}$.

c. Hubungan masyarakat membangun hubungan baik dengan berbagai kalangan untuk mendapatkan publisitas yang diinginkan, membangun citra perusahaan yang baik, dan menangani atau menghadapi rumor, berita, dan kejadian tidak menyenangkan. Hubungan masyarakat dapat membawa dampak yang luar biasa terhadap kesadaran publik padahal biayanya yang jauh lebih murah ketimbang iklan. Perusahaan tidak membayar ruang atau waktu siar dalam media.Sebaliknya, perusahaan membayar staf untuk mengembangkan dan menyiarkan informasi serta mengelola kegiatan.

d. Penjualan personal interaksi tatap muka dengan satu atau lebih pembeli

\footnotetext{
${ }^{12}$ Nurdin, N. (2016). The Roles of Information Technology in Islamic Bank Knowledge Management: A study of Two Syariah Banks in Palu. HUNAFA : Jurnal Studia Islamika, 13(2), 181 - 217.
}

prospektif untuk tujuan melakukan persentasi, menjawab pertanyaan, dan pengadaan pesanan.

e. Pemasaran langsungsistem pemasaran interaktif yang menggunakan satu atau lebih media iklan untuk menghasilkan tanggapan dan/atau transaksi yang dapat diukur pada suatu lokasi.

\section{Pengambilan Keputusan}

Fandy Tjiptono dalam Wijaya, dkk. Menyatakan bahwa pengambilan keputusan konsumen sangat bervariasi, ada yang sederhana, ada juga yang kompleks.Proses pengambilan keputusan yang luas merupakan jenis pengambilan keputusan yang paling lengkap. Bermula dari pengenalan masalah konsumen yang dapat dipecahkan melalui pembelian beberapa produk. Untuk keperluan ini, konsumen mencari informasi tentang produk atau merek tertentu dan mengevaluasi seberapa baik masing-masing alternatif tersebut dapat memecahkan masalahnya. Evaluasi produk atau merek, akan mengarah pada keputusan pembelian. ${ }^{13}$

Menurut Kotler bahwa keputusan untuk membeli yang diambiloleh pembeli sebenarnya merupakan kumpulan dari sejumlah keputusan. Setiapkeputusan untuk

\footnotetext{
${ }^{13}$ Erwin Adi Wijaya, dkk. "Pengaruh Citra Merek Terhadap Keputusan PembelianSmartphone Samsung Galaxy Series Pada MahasiswaIlmu Administrasi Bisnis," jurnal ilmu [t.th], h. 3. (Diakses 15 Juni 2017).
} 
membeli tersebut mempunyai suatu struktur sebanyak tujuhkomponen, yang meliputi: ${ }^{14}$

a. Keputusan tentang jenis produk

Dalam hal ini konsumen dapat mengambil keputusan tentang produk apayang akan dibelinya untuk memenuhi dan memuaskan kebutuhan.

b. Keputusan tentang bentuk produk

Konsumen dapat mengambil keputusan untuk membeli suatu produkdengan bentuk tertentu sesuai dengan seleranya.

c. Keputusan tentang merek

Konsumen harus mengambil keputusan tentang merek mana yang akandibeli karena setiap merek mempunyai perbedaan-perbedaan tersendiri.

d. Keputusan tentang penjualnya

Konsumen dapat mengambil keputusan dimana produk yang dibutuhkantersebut akan dibeli.

e. Keputusan tentang jumlah produk

Konsumen dapat mengambil keputusan tentang seberapa banyak produkyang akan dibeli.

f. Keputusan tentang waktu pembelian Konsumen dapat mengambil keputusan tentang kapan dia harusmelakukan pembelian.

g. Keputusan tentang cara pembayaran

${ }^{14}$ Kotler, Philip. Manajemen Pemasaran. Edisi ke-13, Jilid 1. (Terjemahan: Bob Sabran. Jakarta: Erlangga, 2010), h. 234.
Konsumen dapat mengambil keputusan tentang metode atau carapembelian produk yang akan dibeli,apakah secara tunai atau kredit.

Keputusan tersebut akan mempengaruhi keputusan tentang penjualan danjumlah pembeliannya.Proses keputusan pembelian oleh konsumen secara umum mempunyaikarakteristik yang hampir sama. Hal tersebut dapat dilihat dari kecenderunganumum konsumen dalam melakukan suatu proses pembelian. Menurut Kotlerdan Amstrong, proses pembelian oleh konsumen secara umumadalah sebagai berikut: ${ }^{15}$

a. Pengenalan kebutuhan (need recognition)

Terjadi dimana pembeli mengenali masalah atau kebutuhan. Tahap ini sedikit banyak dipengaruhi oleh bagaimana pengetahuan konsumen akan pembelian. Dimensi dasar dari pengenalan kebutuhan melibatkan informasi berkenaan dengan keputusan tentang di mana produk tersebut harus dibeli dan kapan pembelian harus terjadi.

b. Pencarian informasi (information research)

Pencarian informasi merupakan tahap proses pengambilan keputusan pembeli

${ }^{15}$ Wayan Adi Virayan,"Pengaruh Harga, Kualitas Produk, dan Citra Merek terhadap Keputusan Pembelian," (Skripsi, Fakultas Ekonomi Universitas Negeri Yogyakarta, 2013), h. 24-25, (Diakses 7 juni 2017). 
dimana konsumen telah tertarik untuk mencari lebih banyak informasi: konsumen mungkin hanya meningkatkan perhatian atau mungkin aktif mencari informasi. Pada tahap ini seorang yang telah tertarik akan suatu produk mungkin akan mencari lebih banyak informasi. Jika dorongan konsumen begitu kuat dan produk yang memuaskan berada dalam jangkauan, konsumen kemungkinan besar akan melakukan pembelian. Namun demikian jika tidak, konsumen kemungkinan menyimpan kebutuhannya dalam ingatan atau melakukan pencarian informasi yang berkaitan dengan kebutuhan itu.

c. Evaluasi Berbagai Alternatif (alternative evaluation)

Evaluasi merupakan tahap dalam proses pengambilan keputusan pembeli dimana konsumen menggunakan informasi untuk mengevaluasi merek-merek alternatif dalam satu susunan pilihan.

d. Keputusan Pembelian (purchase
decision)

Keputusan pembelian merupakan tahap dalam proses pengambilan keputusan pembeli dimana konsumen benar-benar membeli produk.

e. Perilaku Pasca Pembelian (postpurchase behaviour)

Perilaku pasca pembelian merupakan tahap dalam proses pengambilan keputusan pembeli dimana konsumen mengambil tindakan lebih lanjut setelah membeli berdasarkan kepuasan yang mereka rasakan.

Proses pengambilan keputusan tersebut di atas sangat berpengaruh padaprospek pemasaran pada saat ini maupun mendatang. Hal tersebut karenapemasaran tidak berhenti dengan terjualnya suatu produk. Pemasaran mencakup proses konsumsi. Tenaga-tenaga pemasaran ingin konsumennyapuas setelah mengkonsumsi produknya sehingga pembeli kemungkinan akanmembeli kembali. Pada kenyataannya, kerena konsumen tidak ingin mengalami proses keputusan yang rumit ung. setiap pembelian, pembeliseringkali membeli kembali produk-produk yang telah mereka gunakan dansukai.

Adapun keputusan membeli menurut Islam yaitu melarang membelanjakan harta secara berlebih-lebihan semata-mata menuruti hawa nafsu, sementara disisi lain juga mengutuk perbuatan menjauhkan diri dari kesenangan menikmati benda-benda yang baik dalam kehidupan. Selain itu konsep pengambilan keputusan dalam islam dijelaskan pula ayat tentang sikap hati-hati dalam menerima informasi seperti yang dijelaskan dalam QS. Al-Hujurat (49) : $6:{ }^{16}$

\footnotetext{
${ }^{16}$ Agustitin Setyana, "Pengaruh Brand Image Toko terhadap Keputusan Pembelian", (Skripsi, Fakultas Ekonomi Dan Bisnis Islam IAIN Purwokerto, 2015), h. 53. (Diakses 14 Juni 2017).
} 


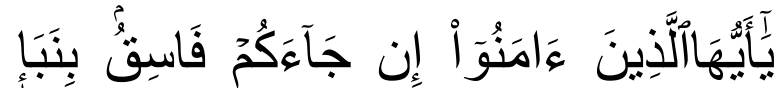

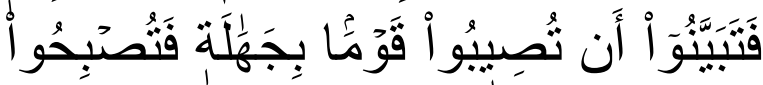

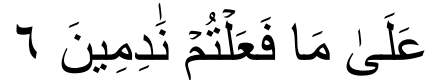

Terjemahnya :

"Hai orang-orang yang beriman, jika datang kepadamu orang fasik membawa suatu berita, maka periksalah dengan teliti agar kamu tidak menimpakan suatu musibah kepada suatu kaum tanpa mengetahui keadaannya yang menyebabkan kamu menyesal atas perbuatanmu itu". ${ }^{17}$

Berdasarkan ayat di atas dapat diketahui bahwa sebagai umat muslim hendaknya berhati-hati dalam menerima suatu berita atau informasi. Ketika kita tidak mempunyai pengetahuan tentang hal tersebut maka sebaiknya kita periksa dan teliti terlebih dahulu sebelum akhirnya menyesal dikemudian hari. Ayat ini juga dapat disandarkan dengan sikap hati-hati umat islam dalam membuat keputusan untuk mengkonsumsi atau menggunakan suatu produk. Seperti yang dijelaskan sebelumnya bahwa terdapat tahap-tahap yang dilalui seseorang dalam pengambilan keputusan konsumen, dimulai dari pengenalan kebutuhan, pencarian informasi, pemilihan alternative, pengambilan keputusan dan perilaku pasca pembelian.

Sebelum memutuskan untuk membeli atau menggunakan suatu produk hendaknya h. 742 . konsumen terlebih dahulu mencari informasi apakah produk tersebut baik atau tidak. Hal inilah yang menjadi alasan betapa pentingnya mencari informasi terkait suatu informasi atau berita yang datang.

\section{Tabungan}

Menurut Lapoliwa dan Kuswandi tabungan adalah simpanan masyarakat yang penarikannya dapat dilakukan oleh si penabung sewaktu - waktu dikehendaki. ${ }^{18}$

Sedangkan menurut Siamat tabungan adalah simpanan yang penarikannya hanya dapat dilakukan menurut syariat tertentu yang disepakati, tetapi tidak dapat ditarik dengan cek dan bilyet giro. ${ }^{19}$

Berdasarkan pendapat para ahli di atas, maka dapat disimpulkan bahwa tabungan merupakan bagian dari pendapatan seseorang yang tidak digunakan, dan disimpan pada lembaga perbankan dalam bentuk simpanan tabungan, yang penarikannya hanya dapat dilakukan berdasarkan syarat - syarat tertentu.

${ }^{18}$ Lapoliwa dan Daniel Kuswandi. Akuntansi Perbankan Transaksi Bank dalam Valuta Rupiah, (Jakarta: Penerbit Institut Bankir Indonesia 2000), 73.

${ }^{19}$ Dahlan Siamat. Manajemen Lembaga Keuangan, Kebijakan Moneter dan Perbankan, (Jakarta: Penerbit Fakultas Ekonomi Universitas Indonesia 2005), 301. 
Menurut Kasmirjenis-jenis tabungan yang ada pada sebagian bank Indonesia, terdiri dari $:^{20}$

a. Tabanas (Tabungan Pembangunan Nasional), yaitu tabungan yang tidak terkait untuk jangka waktu, dan penarikannya hanya dapat dilakukan dengan syarat - syarat tertentu, yaitu sebanyak dua kali dalam sebulan.

b. Taska (Tabungan Asuransi Berjangka), yaitu tabungan yang berhubungan erat kaitannya dengan asuransi jiwa dan jaminan bagi nasabah serta penyetorannya dilakukan setiap bulan.

c. Tabungan ONH (Ongkos Naik Haji), yaitu setoran ongkos naik haji dan setoran - setoran dimuka berdasarkan peraturan peraturan yang di tetapkan setiap bulannya.

d. Tabungan lainnya, yaitu jenis tabungan selain tabungan di atas. Tabungan ini dikeluarkan oleh masing - masing bank dengan ketentuan - ketentuan yang di atur oleh bank Indonesia (BI).

iB adalah singkatan dari Islamic Banking dan dipopulerkan sebagai penanda identitas bersama industri perbankan syariah di Indonesia yang diresmikan sejak 2 Juli 2007. Penggunaan identitas bersama ini bertujuan agar masyarakat dengan mudah

${ }^{20}$ Kasmir, Bank dan Lembaga Keuangan Lainnya Edisi Revisi, (Jakarta: PT. Raja Grafindo Persada 2008), 80. dan cepat mengenali tersedianya layanan jasa perbankan syariah di seluruh Indonesia. iB merupakan penanda identitas industri perbankan syariah di Indonesia, yang merupakan kristalisasi dari nilai-nilai utama sistem perbankan syariah yang modern, transparan, berkeadilan, seimbang dan beretika yang selalu mengedepankan nilainilai kebersamaan dan kemitraan. Dengan semakin banyaknya bank yang menawarkan produk dan jasa perbankan syariah, kehadiran logo iB akan memudahkan masyarakat untuk mengenali secara cepat dan menemukan kelebihan layanan perbankan syariah untuk kebutuhan transaksi keuangannya. ${ }^{21}$

\subsection{Model Penelitian}

Promosi merupakan suatu kegiatan untuk membujuk konsumen, dimana perusahaan mengkomunikasikan mengenai produk, jasa, ataupun ide yang ditawarkan kepada konsumen, agar konsumen tersebut dapat melakukan keputusan pembelian. Dalam menjalankan strategi promosi, perusahaan dapat memilih alat promosi yang akan digunakan, yang terdiri dari periklanan, promosi penjualan, hubungan masyarakat, penjualan personal, dan pemasaran langsung. Berdasarkan hal tersebut, maka dirumuskan untuk mengukur Pengaruh Bauran Promosi (Periklanan, Promosi

${ }^{21}$ Yogie Respati, Arti Logo iB Pada Bank Syariah (Jakarta: Pustaka Ishlahul Ummah, 2015), 28 
Penjualan, Hubungan Masyarakat, Penjualan personal, dan Pemasaran Langsung) Terhadap Keputusan Nasabah dalam Menggunakan Tabungan iB Hasanah Pada PT. BNI Syariah Cabang Palu, dalam bentuk analisis kuantitatif (regresi linear berganda), maka penulis membuat suatu kerangka penelitian sebagai berikut:

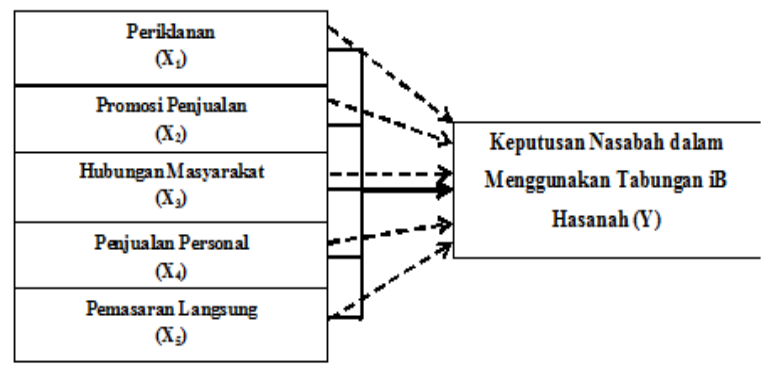

Gambar 1. Model Penelitian

\section{METODOLOGI}

Jenis penelitian ini adalah penelitian verifikatif yaitu jenis penelitian yang bertujuan untuk menguji suatu teori atau hasil penelitian sebelumnya, sehingga diperoleh hasil yang memperkuat atau menggugurkan teori atau hasil penelitian sebelumnya.

Pendekatan yang digunakan dalam penelitian ini adalah pendekatan kuantitatif, karena penelitian ini terfokus untuk mengetahui pengaruh bauran promosi terhadap keputusan nasabah menggunakan tabungan iB hasanah pada PT. BNI Syariah Cabang Palu. melalui perolehan hasil data berbentuk angka-angka yang selanjutnya akan dilakukan analisis melalui statistik. ${ }^{22}$

Penelitian ini menggunakan teknik sampling insidental. Teknik sampling insidental sampling adalah teknik menentukan sampel berdasarkan kebetulan, yaitu siapa saja yang secara kebetulan atau insidental bertemu dengan Peneliti dapat digunakan sebagai sampel jika orang tersebut dipandang cocok untuk dijadikan sampel. ${ }^{23}$

Berdasarkan petunjuk di atas maka jumlah sampel pada penelitian ini ditetapkan dengan perhitungan yaitu $10 \times 6=60(50$ Orang responden). 6 merupakan banyaknya jumlah variabel (independen + dependen) dalam penelitian ini.

Data diolah dengan menggunakan SPSS. Kemudian dilakukan uji statistik F untuk menunjukkan apakah semua variabel independen atau bebas yang dimasukkan dalam model mempunyai pengaruh secara bersaama-sama terhadap variabel dependen/terikat. ${ }^{24}$

Untuk mengetahui apakah variabel independen berpengaruh signifikan terhadap variabel dependen, dilakukan perbandingan

${ }^{22}$ Rully Indrawan dan R Poppy Yaniawati, Metode Penelitian, Cet. I (Bandung : PT. Rafika Aditama, 2014), 117.

${ }^{23}$ Sugiono, Metode Penelitian Pendidikan, (Bandung: Alfabeta, 2010), 125.

${ }^{24}$ Imam Gozali, Aplikasi Analisis Multivariate dengan Program IBM SPSS 21, Edisi ketujuh (Semarang: Badan Penerbit Universitas Diponegoro, 2013), 98. 
antara $F_{\text {hitung }}$ dengan $F_{\text {tabel }}$ pada tingkat kepercayaan 0,05. Dalam uji ini digunakan rumus yang dikemukakan Riduan. ${ }^{25}$

\section{HASIL DAN PEMBAHASAN}

\subsection{Gambaran Lokasi Penelitian}

Tempaan krisis moneter tahun 1997 membutikan ketangguhan sistem perbankan syariah. Prinsip syariah dengan 3 (tiga) pilar yaitu adil, transparan dan maslahat mampu menjawab kebutuhan masyarakat terhadap sistem perbankan yang lebih adil. Dengan berlandaskan pada Undang-undang No. 10 Tahun 1998, pada tanggal 29 April 2000 didirikan Unit Usaha Syariah (UUS) BNI dengan 5 kantor cabang di Yogyakarta, Malang, Pekalongan, Jepara, dan Banjarmasin. Selanjutnya UUS BNI terus berkembang menjadi 28 kantor cabang dan 31 Kantor Cabang Pembantu.

Disamping itu nasabah juga dapat menikmati layanan syariah di Kantor Cabang BNI Konvensional ( office channeling) dengan lebih kurang 1500 outlet yang tersebar diseluruh wilayah Indonesia. Di dalam pelaksanaan operasional perbankan, BNI Syariah tetap memperhatikan kepatuhan terhadap aspek syariah. Dengan Dewan Pengawas Syariah (DPS) yang saat ini di ketuai oleh KH. Ma'ruf Amin, semua produk BNI Syariah telah melalui pengujian dari

\footnotetext{
${ }^{25}$ Riduwan, Penelitian untuk Guru, Karyawan dan Peneliti Pemula, (Bandung: Alfabeta, 2012), 142.
}

DPS sehingga telah memenuhi aturan syariah.

Berdasarkan Keputusan Gubernur Bank Indonesia Nomor 12/41/KEP.GBI/2010 tanggal 21 Mei 2010 mengenai pemberian izin usaha kepada PT Bank BNI Syariah. Dan di dalam Corporate Plan UUS BNI tahun 2003 ditetapkan bahwa status UUS bersifat temporer dan akan dilakukan spin off tahun 2009, rencana tersebut terlaksana pada tanggal 19 Juni 2010 dengan beroperasinya BNI Syariah sebagai Bank Umum Syariah (BUS). Realisasi waktu spin off bulan juni 2010 tidak terlepas dari faktor eksternal berupa aspek regulasi yang kondusif yaitu dengan diterbitkanya UU No. 19 tahun 2008 tentang Surat Berharga Syariah Negara (SBSN) dan UU No. 21 tahun 2008 tentang Perbankan Syariah. Disamping itu, komitmen Pemerintah terhadap pengembangan perbankan syariah semakin kuat dan kesadaran terhadap keunggulan produk perbankan syariah juga semakin meningkat.

\subsection{Karakteristik Responden}

Penelitian ini dilakukan di PT. BNI Syariah Cabang Palu. Data penelitian menggunakan kuesioner yang dibagikan kepada nasabah tabungan iB Hasanah sebagai sampel penelitian. Penyebaran kuesioner disebarkan oleh peneliti kepada 
sampel yang diteliti dengan perincian sebagai berikut:

Tabel 1. Karakteristik Responden

\begin{tabular}{|c|l|c|c|}
\hline No & \multicolumn{1}{|c|}{ Pekerjaan } & Jumlah & Persentase $\%$ \\
\hline 1. & Pegawai Negeri Sipil (PNS) & 13 Orang & $22 \%$ \\
\hline 2. & Pegawai Swasta & 31 Orang & $52 \%$ \\
\hline 3. & Wiraswasta/Pedagang & 2 Orang & $3 \%$ \\
\hline 4. & Mahasiswa/Pelajar & 5 Orang & $8 \%$ \\
\hline 5. & TNI/POLRI & 3 Orang & $5 \%$ \\
\hline 6. & Lainnya & 6 Orang & $10 \%$ \\
\hline \multicolumn{2}{|c|}{ Jumlah } & $\mathbf{6 0}$ Orang & $\mathbf{1 0 0} \%$ \\
\hline
\end{tabular}

Data di atas, diketahui dari 60 responden jenis pekerjaan pegawai swasta memiliki jumlah frekuensi paling tinggi yaitu $52 \%$ atau 31 orang responden. Hal tersebut menggambarkan bahwa pegawai swasta lebih banyak memiliki waktu luang berkunjung di PT. Bank BNI Syariah Cabang Palu.

\subsection{Hasil Analisa Angket}

Berdasarkan hasil analisa angket, dapat diketahui bahwa tanggapan responden terhadap indikator-indikator variabel promosi penjualan (X2) pada kuesioner, pernyataan yang pertama yaitu tanggapan responden tidak ada yang menjawab sangat tidak setuju, 1 orang menjawab tidak setuju dengan nilai persentase $1,67 \%, 4$ orang menjawab kurang setuju dengan nilai persentase $6,67 \%, 31$ orang menjawab setuju dengan nilai persentase $51,66 \%$, dan 24 orang menjawab sangat setuju dengan nilai persentase $40 \%$. Maka total rata-rata jawaban dari nilai mean adalah 4,3.

Pada pernyataan kedua promosi penjualan (X2) menunjukkan tanggapan responden yaitu tidak ada yang menjawab sangat tidak setuju, tidak ada menjawab tidak setuju, 2 orang menjawab kurang setuju dengan nilai persentase $3,3 \%, 8$ orang menjawab setuju dengan nilai persentase $13,3 \%$, dan 50 orang menjawab sangat setuju dengan nilai presentase $83,4 \%$. Maka total rata-rata jawaban dari nilai mean 4,8 .

Pada pernyataan ketiga promosi penjualan (X2) menunjukkan tanggapan responden yaitu tidak ada yang menjawab sangat tidak setuju, 1 orang yang menjawab tidak setuju dengan nilai persentase $1,67 \%, 7$ orang menjawab kurang setuju dengan nilai persentase $11,67 \%, 26$ orang menjawab setuju dengan nilai persentase 43,3\%, dan 26 orang menjawab sangat setuju dengan nilai presentase $43,3 \%$. Maka total rata-rata jawaban dari nilai mean 4,28.

Rata-rata dari keseluruhan jawaban responden terhadap variabel promosi penjualan adalah sebesar 4,46 yaitu termasuk dalam kriteria sangat baik.

Kemudian hasil pengolahan angket terkait tanggapan responden terhadap indikator-indikator variabel hubungan masyarakat (X3) pada kuesioner, pernyataan yang pertama yaitu tanggapan responden tidak ada yang menjawab sangat tidak setuju, tidak ada yang menjawab tidak setuju, 2 orang menjawab kurang setuju dengan nilai persentase $3,3 \%, 28$ orang menjawab setuju dengan nilai persentase 48,67 , dan 30 orang menjawab sangat setuju dengan nilai 
persentase $50 \%$. Maka total rata-rata jawaban dari nilai mean adalah 4,46.

Pada pernyataan kedua hubungan masyarakat (X3) menunjukkan tanggapan responden yaitu tidak ada yang menjawab sangat tidak setuju, 1 orang menjawab tidak setuju dengan nilai persentase 1,67\%, 6 orang menjawab kurang setuju dengan nilai persentase $10 \%, 33$ orang menjawab setuju dengan nilai persentase $55 \%$, dan 20 orang menjawab sangat setuju dengan nilai presentase $33,3 \%$. Maka total rata-rata jawaban dari nilai mean 4,2.

Pada pernyataan ketiga hubungan masyarakat (X3) menunjukkan tanggapan responden yaitu tidak ada yang menjawab sangat tidak setuju, tidak ada yang menjawab tidak setuju, 3 orang menjawab kurang setuju dengan nilai persentase $5 \%, 26$ orang menjawab setuju dengan nilai persentase $43,3 \%$, dan 31 orang menjawab sangat setuju dengan nilai presentase $51,67 \%$. Maka total rata-rata jawaban dari nilai mean 4,46.

Pada pernyataan keempat hubungan masyarakat (X3) menunjukkan tanggapan responden yaitu tidak ada yang menjawab sangat tidak setuju, tidak ada yang menjawab tidak setuju, 3 orang yang menjawab kurang setuju dengan nilai persentase $5 \%, 27$ orang yang menjawab setuju dengan nilai persentase $45 \%$, 30 orang menjawab sangat setuju dengan nilai persentase 50\%. Maka total rata-rata jawaban dari nilai mean 4,45.
Pada pernyataan ke lima hubungan masyarakat (X3) menunjukkan tanggapan responden yaitu tidak ada yang menjawab sangat tidak setuju, tidak ada menjawab tidak setuju, 3 orang yang menjawab kurang setuju dengan nilai persentase 5\%, 45 orang yang menjawab setuju dengan nilai persentase $75 \%$, dan 12 orang menjawab sangat setuju dengan nilai presentase $20 \%$. Maka total rata-rata jawaban dari nilai mean 4,15 .

Rata-rata dari keseluruhan jawi I responden terhadap variabel hubungan masyarakat adalah sebesar 4,344 yaitu termasuk dalam kriteria sangat baik.

\subsection{Pembahasan}

Bardasarkan hasil analisis uji regresi pengaruh bauran promosi terhadap keputusan nasabah dalam menggunakan tabungan iB hasanah pada PT. BNI syariah Cabang Palu, menunjukan bahwa secara serempak memiliki pengaruh yang sangat signifikan terhadap keputusan nasabah. Secara parsial juga menunjukan adanya pengaruh yang signifikan kecuali variabel Hubungan Masyarakat (X3) dan Pemasaran Langsung (X5).

a. Berdasarkan hasil analisis data bahwa secara serempak dan parsial terdapat nilai konstant 11.930 dan dilanjutkan dengan hasil uji $F_{\text {hitung sebesar 27,159 }>F_{\text {tabel }}}$ sebesar 2,54 dan tingkat signifikan lebih kecil dari taraf ketidakpercayaan 5\% (0,0 
$00<0,05)$, sangat berpengaruh terhadap keputusan nasabah menggunakan tabungan iB Hasanah pada BNI Syariah Cabang Palu.

b. Pengaruh parsial Periklanan berdasarkan pada uji $\mathrm{T}_{\text {hirung }}$ sebesar $2,131>\mathrm{T}_{\text {tabel }}$ sebesar 2,004 dan tingkat signifikasinya lebih kecil dari taraf ketidakpercayaan 5\% $(0,036<0,05)$ menunjukkan bahwa berpengaruh secara parsial dan signifikan terhadap keputusan membeli.

c. Pengaruh parsial Promosi Penjualan mempunyai nilai $\mathrm{T}_{\text {hitung }}$ sebesar $4,251>$ $\mathrm{T}_{\text {tabel }}$ 2,004 dan tingkat signifikan lebih besar dari taraf ketidakpercayaan 5\% $(0,000<0,05)$ menunjukkan bahwa berpengaruh secara parsial dan signifikan terhadap keputusan nasabah. Apabila dilihat dari hasil uji t variabel $\operatorname{Pr}$ Penjualan yang lebih signifikan memberikan pengaruh terhadap keputusan nasabah.

d. Pengaruh parsial Hubungan Masyarakat mempunyai nilai $\mathrm{T}_{\text {hitung }}$ sebesar $1,1901<$ $\mathrm{T}_{\text {tabel }}$ 2,004 dan tingkat signifikan lebih besar dari taraf ketidakpercayaan 5\% $(0,061>0,05)$ menunjukkan bahwa tidak berpengaruh terhadap keputusan nasabah. Apabila dilihat dari jawaban responden ternyata hubungan masyarakat tidak mempengaruhi nasabah iB hasanah dalam menggunakan tabungan iB hasanah pada BNI Syariah Cab.Palu. e. Pengaruh parsial Penjualan personal berdasarkan pada uji $\mathrm{T}_{\text {hirung }}$ sebesar 2,050 $>\mathrm{T}_{\text {tabel }}$ sebesar 2,004 dan tingkat signifikasinya lebih kecil dari taraf ketidakpercayaan $5 \%(0,026<0,05)$ menunjukkan bahwa berpengaruh secara parsial dan signifikan terhadap keputusan nasabah

f. Pengaruh parsial pemasaran langsung mempunyai nilai $\mathrm{T}_{\text {hitung }}$ sebesar $0,819<$ $\mathrm{T}_{\text {tabel }}$ 2,004 dan tingkat signifikan lebih besar dari taraf ketidakpercayaan 5\% $(0,417>0,05)$ menunjukkan bahwa tidak berpengaruh terhadap keputusan nasabah.

Untuk mengetahui seberapa besar kontribusi variabel periklanan, promosi penjualan, hubungan masyarakat, penjualan personal dan pemasaran langsung dalam upaya mempengaruhi variabel keputusan nasabah dapat diwakili oleh besarnya koefisien determinasi. Sebagaimana sudah diuraikan di atas, bahwa nilai koefisien determinasi yang dinotasikan dengan Adjusted R Square adalah sebesar 0,844 ini artinya besar pengaruh variabel independen terhadap variabel dependen adalah 0,844 ini menunjukkan bahwa merek, fitur dan iklan dapat memberikan pengaruh terhadap keputusan membeli sebesar $84,4 \%$ sisanya 15,6\% dipengaruhi oleh faktor lain yang tidak diteliti.

\section{KESIMPULAN DAN IMPLIKASI}


Berdasarkan hasil penelitian Pengaruh Bauran Promosi Terhadap Keputusan Nasabah Menggunakan Tabungan iB Hasanah Pada PT.BNI Syariah Cabang Palu" dari hasil data di lapangan dapat disimpulkan bahwa:

Berdasarkan hasil uji ANOVA (Analysis of Varians) atau $\mathrm{F}$ test diperoleh nilai F-hitung sebesar 27,159> F-tabel sebesar 2,54 dan tingkat signifikan lebih kecil dari taraf ketidakpercayaan 5\% (0,000 $<$ 0,05). Dengan demikian hasil ini memberikan makna bahwa periklanan, penjualan personal, hubungan masyarakat, promosi penjualan dan pemasaran langsung secara serempak berpengaruh signifikan terhadap keputusan nasabah.

Kelima variabel yaitu, Periklanan, Penjualan Personal, dan Promosi Penjualan berpengaruh secara parsial terhadap Keputusan Nasabah sedangkan hubungan masyarakat dan pemasaran langsunPg tidak memberikan pengaruh secara parsial.Analisis regresi linear berganda menunjukkan bahwa koefisien korelasi determinasi yang dinotasikan dengan adjusted $\mathrm{R}$ square besarnya 0,844 ini menunjukkan bahwa Periklanan, Penjualan Personal, Hubungan Masyarakat, Promosi Penjualan dan Pemasaran Langsung memberikan pengaruh terhadap Keputusan Nasabah sebesar $84,4 \%$ sisanya $15,6 \%$ dipengaruhi oleh faktor lain yang tidak diteliti.

Selanjutnya peneliti menyampaikan saran-saran yang kiranya dapat memberikan manfaat kepada pihak-pihak yang terkait atas hasil penelitian ini. Adapun saran-saran yang disampaikan adalah sebagai berikut:

Sehubungan dengan variabel periklanan, penjualan personal, hubungan masyarakat, promosi penjualan dan pemasaran langsung dapat mempengaruhi secara signifikan terhadap keputusan nasabah maka disarankan agar PT.BNI Syariah Cabang Paluharus terus mengontrol dan meningkatkan variabel-variabel yang terbukti memberikan pengaruh yang signifikan terhadap keputusan nasabah seperti variabel periklanan, promosi penjualan, dan penjualan personal dalam melakukan pembelian atau penggunaan produk/jasa, dan jugayang paling perlu diperhatikan ialah variabel-variabel yang terbukti memberikan pengaruh tidak signifikan terhadap keputusan nasabah seperti variabel hubungan masyarakat dan pemasaran langsung dalam melakukan pembelian atau penggunaan produk/jasa, agar terjadi peningkatan baik dari segi produktivitas dan efektivitas maupun dari segi keuntungan PT. BNI Syariah Cabang Palu.

Untuk penelitian selanjutnya, diharapkan untuk mencari, menambahkan, 
atau bahkan mengkombinasikan variabelvariabel pembentuk keputusan nasabah pada PT. BNI Syariah Cabang Palu, agar hasil penelitiannya memberikan kontribusi yang bermakna pada pihak-pihak yang berkepentingan.

\section{DAFTAR PUSTAKA}

Budianto, Apri. Manajemen Pemasaran, Edisi Revisi, (Yogyakarta: Penerbit Ombak, 2015).

Bachmid, Sofyan “ Konsep Kualitas Layanan Dan Implikasinya Terhadap Kepuasan Mahasiswa". Jurnal Finlansia (2012). http://www.academia.edu/4705098/K ONSEP_KUALITAS_LAYANAN DAN_IMPLIKASINYA TERHADA P_KEPUASAN_MAHASISWA_OL EH_SOFYAN_BACHMID (diakses 15 Juni 2017)

Darna. "Pengaruh Bauran Promosi Terhadap Keputusan Pengambilan Produk Pembiayaan KPR Platinum iB Pada Bank X Syariah Cabang Harmoni Jakarta", Jurnal Ekonomi dan Bisnis, Vol 12, No 1 (juni 2013), 8. (Diakses 10 Mei 2017).

Faisal, Iman Agus. "Pengaruh Bauran Promosi Terhadap Keputusan Nasabah Pada Pt. Bni Cabang Palu", (Skripsi, Jurusan Manajemen Fakultas Ekonomi Universitas Tadulako, 2016), 4. (Diakses $10 \mathrm{Mei}$ 2017).

Gozali, Imam. Aplikasi Analisis Multivariate dengan Program IBM SPSS 21, Edisi ketujuh (Semarang: Badan Penerbit Universitas Diponegoro, 2013).

Hafidhuddin." Efektivitas Iklan Pada Media Cetak Terhadap Keputusan Konsumen Menggunakan Ib Hasanah
Card Bni Syariah", (Skripsi, UIN Jakarta 2015), 16. (Diakses 10 Mei 2017)

Indrawan, Rully dan R Poppy Yaniawati. Metode Penelitian, Cet. I (Bandung : PT. Rafika Aditama, 2014).

Kasmir. Bank dan Lembaga Keuangan Lainnya Edisi Revisi, (Jakarta: PT. Raja Grafindo Persada 2008).

Kementrian Agama Republik Indonesia, AlQur'an dan Terjemahnya (Surabaya: Mekar Surabaya, 2002).

Kotler, Philip dan Gary Armstrong. Prinsip - Prinsip Pemasaran Edisi Keduabelas, jilid 2, (Jakarta: Penerbit Erlangga 2008).

Kotler, Philip. Manajemen Pemasaran. Edisi ke-13, Jilid 1. (Terjemahan: Bob Sabran. Jakarta: Erlangga, 2010).

Kotler, Philip. Manajemen Pemasaran. Edisi ke-13, Jilid 1. (Terjemahan: Bob Sabran. Jakarta: Erlangga, 2010).

Lapoliwa dan Daniel Kuswandi. Akuntansi Perbankan Transaksi Bank dalam Valuta Rupiah, (Jakarta: Penerbit Institut Bankir Indonesia 2000).

Nurdin, N. (2016). The Roles of Information Technology in Islamic Bank Knowledge Management: A study of Two Syariah Banks in Palu. HUNAFA : Jurnal Studia Islamika, 13(2), 181 - 217.

Respati, Yogie. Arti Logo iB Pada Bank Syariah (Jakarta: Pustaka Ishlahul Ummah, 2015).

Riduwan. Penelitian untuk Guru, Karyawan dan Peneliti Pemula, (Bandung: Alfabeta, 2012). 
Ruslan, Rosady. Metode Penelitian Public Relations dan Komunikasi (Jakarta: PT Raja Grafindo Persada, 2003).

Rusyana, Riduan Adun Enas, Cara mudah belajar SPSS 17.0 dan Aplikasi Statistik Penelitian, (Cet.III, Bandung: Alfabeta, 2013).

Sarjono Haryadi dan Winda Julianita, SPSS vs Lisrel Sebuah Pengantar, Aplikasi Untuk Riset, (Jakarta: Salemba Empat,2011).

Siamat, Dahlan. Manajemen Lembaga Keuangan, Kebijakan Moneter dan Perbankan, (Jakarta: Penerbit Fakultas Ekonomi Universitas Indonesia 2005).

Setyana, Agustitin. "Pengaruh Brand Image Toko terhadap Keputusan Pembelian", (Skripsi, Fakultas Ekonomi Dan Bisnis Islam IAIN Purwokerto, 2015), h. 53. (Diakses 14 Juni 2017).

ISugiono. Metode Penelitian Kuantitatif Kualitatif dan $R \& D$, (Bandung: CV Alfabeta, 2009).

Sugiono, Metode Penelitian Pendidikan, (Bandung: Alfabeta, 2010).

Sugiono, Metode Penelitian Kuantitatif, Kualitatif dan $R$ an $D$, Cet. XIX, (Bandung: CV. Alfabeta, 2011).
Sugiyono, Metode Penelitian Kombinasi, (Bandung: CV Alfabeta, 2015).

Sunyoto, Danang. Analisis Regresi dan Uji Hipotesis, (Yogyakarta: CAPS, 2011).

Tjiptono, F. Strategi Pemasaran, Edisi Ketiga, (Yogyakarta: CV. Andi Offset, 2008).

Tjiptono, F. Strategi Pemasaran,

Umar, Husein. Metode Riset Perilaku konsumen Jasa, (Jakarta: Ghalia Indonesia, 2003).

Uyun, Khoirul. "Pengaruh Produk Syari'ah dan Bauran Promosi Terhadap Keputusan Nasabah Menabung Di Bni Syari'a h Cabang Semarang", (Skripsi. Semarang: IAIN Walisongo Semarang 2012), 10. (Diakses 10 Mei 2017).

Virayan, Wayan Adi. "Pengaruh Harga, Kualitas Produk, dan Citra Merek terhadap Keputusan Pembelian," (Skripsi, Fakultas Ekonomi Universitas Negeri Yogyakarta, 2013), h. 24-25, (Diakses 7 juni 2017).

Wijaya, Erwin Adi. dkk. "Pengaruh Citra Merek Terhadap Keputusan Pembelian Smartphone Samsung Galaxy Series Pada Mahasiswa Ilmu Administrasi Bisnis," jurnal ilmu [t.th], . (Diakses 15 Juni 2017). 